\title{
PERBEDAAN RISK PRIORITY NUMBER DALAM FAILURE MODE AND EFFECTS ANALYSIS FMEA SISTEM ALAT BERAT HEAVY DUTY TRUCK HD 785-7
}

\author{
M. Syafwansyah Effendi, M. Khafizd Arifin \\ Jurusan Teknik Mesin Politeknik Negeri Banjarmasin \\ msyafwansyah@gmail.com
}

\begin{abstract}
ABSTRAK
Failure Mode and Efect Analysis (FMEA) adalah jenis desain dan teknologi untuk menganalisis keandalan pencegahan, yang merupakan formula yang sistematis terstruktur untuk mengidentifikasi modus kerusakan yang potensial dalam desain atau manufaktur, kemudian mempelajari pengaruh kerusakan pada sistem, kemudian mengambil langkah-langkah yang diperlukan untuk mengkoreksi dan sebagai metode pencegahan sementara yang mengarah pada masalah dalam sistam keandalan. Secara tradisional, menggunakan teknologi dari FMEA adalah untuk memperbaiki keputusan dalam urutan dari besar Risk Priority Number (RPN) ke yang lebih kecil State of art permasalahan yang mendasar dari RPN Failure and Efect Analysis adalah bagaimana menerapkannya dalam cakupan cukup luas dalam berbagai bidang sebagai alat atau metode yang bermanfaat untuk membantu menjustifikasi pengambilan suatu keputusan dalam menentukan keandalan suatu sistem. Dari penelitian-penelitian yang sudah dilakukan penerapan Model ini banyak dilakukan di lingkungan industri, dan belum ada yang mengapilikasikannya dalam menganalisa mode kegagalan sistem pada peralatan Berat terutama yang dioperasikan disektor pertambangan. Sehingga pada penelitian ini, adalah perlu untuk menguji apakah ada Perbedaan Dalam Risk Priority Number Failure Mode and Effects Analysis Pada Unit Sistem Alat Berat Heavy Duty Truck HD 785-7.

Data diambil dari data History Preventive Maintanance pada sebuah perusahaan tambang di Kalimantan Selatan, selama periode 5 tahun. Unit yang diuji nilai RPN dan sistem adalah Mine Truck Heavy Duty Truck HD 785-7 sebagai sampel diambil 10 unit. Dari data tersebut nilai RPN dihitung masing-masing sistem. Selanjutnya data olahan tersebut di uji dengan uji ANOVA, dengan menggunakan uji F selanjutnya ilakukan analisis untuk setiap kelompok rata-rata atau pasangan rata-rata. Pengujian data dengan menggunakan uji Posteriori (Post Hoc) uji Tukey HSD dan Duncan untuk melihat sistem yang mana dari 15 sistem yang rata-ratanya nilai RPN nya adalah paling kuat berbeda.

Dari hasil pengujian secara statistik, dapat disimpulkan bahwa rata-rata nilai RPN masingmasing sistem adalah berbeda secara signifikan. Dan dari hasil uji Tukey HSD maupun Duncan terlihat bahwa ada tiga sampai empat kelompok rata-rata nilai RPN yang berbeda, dan yang terbesar adalah pada Electric System yaitu rata-rata nilai RPN 197,7
\end{abstract}

Kata Kunci : Failure and Efect Analysis (FMEA), Risk Priority Number (RPN), Sistem, Alat Berat.

\section{PENDAHULUAN}

\section{A. Latar Belakang}

Failure Mode and Efect Analysis (FMEA) adalah jenis desain dan teknologi untuk menganalisis keandalan pencegahan, yang merupakan formula yang sistematis terstruktur untuk mengidentifikasi modus kerusakan yang potensial dalam desain atau manufaktur, kemudian mempelajari pengaruh kerusakan pada sistem, kemudian mengambil langkah-langkah yang diperlukan untuk mengkoreksi dan sebagai metode pencegahan sementara yang mengarah pada masalah dalam sistam keandalan. FMEA telah diadopsi secara luas dan telah menjadi praktek standar di perusahaan manufaktur dalam Jepang, Amerika, dan Eropa (Hung et al, 1999). Sedangkan Ebrahimipour et al (2010) Failure and Efeck Analysis (FMEA) adalah prosedur untuk analisis mode kegagalan potensial dalam sistem klasifikasi berdasarkan tingkat keparahan atau penentuan efek kegagalan pada saat sistem. Ini adalah proses di mana oleh negosiasi organis metodis mengatasi resiko yang melekat pada kegiatan mereka dengan tujuan mencapai keuntungan yang berkelanjutan dalam setiap kegiatan dan seluruh porto folio dari semua kegiatan. 
Chen JK. Dalam Ningcong Xiao et al (2011) menjelaskan bahwa Failure Mode and Efect Analysis (FMEA) adalah alat analisis yang sangat kuat dan efektif yang secara luas digunakan pada proyek-proyek rekayasa untuk memeriksa kemungkinan kegagalan dan menghilangkan potensi kegagalan selama desain sistem. Secara khusus membantu insinyur perencana dengan ukuran kuantitatif atau kualitatif yang diperlukan untuk membantu pelaksanaan tindakan pencegahan yang berfokus pada mode kegagalan utama dan dampaknya terhadap produk.

Secara tradisional, menggunakan teknologi dari FMEA adalah untuk memperbaiki keputusan dalam urutan dari besar Risk Priority Number (RPN) ke yang lebih kecil, tetapi Gilchrist [1993] Ben Daya \& Raouf [1996]; Kara-Zaitri \& Fleming [1997]; Bowles [1998]; Sankar \& Prabhu [2000] telah mengupas perhitungan dari Risk Priority Number. Oleh karena itu, ilmuwan telah mengembangkan beberapa metode lain untuk meningkatkan metode perhitungan RPN tradisional sebelumnya, seperti Kekritisan Skor Evaluasi, Tingkat Risiko, Analisis Kritis dan Metode Matrix, dan lain-lain Tapi metode tersebut masih mirip dengan FMEA tradisional, yang semuanya subyektif mengubah kualitatif menjadi kuantitatif, maka untuk menilai risiko kegagalan dengan konsep fungsi utilitas sebagai dasar untuk meningkatkan urutan prioritas. Tapi apresiasi subjektif menyebabkan kesulitan dalam menetapkan skor yang benar pada FMEA. Dalam rangka meningkatkan standar apresiasi subjektif dari masingmasing faktor dalam $R P N$, beberapa metode baru dikembangkan dalam beberapa tahun terakhir (Jih-Kuang Chen dan Yu-Cheng Lee, 2004).

Sime Curkovic et al (2013) menggambarkan penelitian FMEA digunakan untuk Supply Chain Management,dimana resiko rantai suplai dapat dikurangi untuk sebagian besar dengan kualifikasi dan pemilihan pemasok yang tepat. Tujuan dari penelitiannya adalah untuk mengidentifikasi bagaimana perusahaan mengelola risiko rantai pasokan, dengan fokus khusus pada penggunaan Failure and Efect Analysis (FMEA) yang intinya adalah penentuan nilai $R P N$. Sedangkan Namdari $\mathrm{M}$ et al (2011) mengembankan Penelitian yang bertujuan untuk mengurangi konsumsi bahan bakar di mold board menggunakan Failure and Efect Analysis (FMEA).

Rakesh.R et al (2013) dalam penelitian menggambarkan penggunaan Failure and Efect Analysis (FMEA) untuk meningkatkan keandalan sub sistem untuk memastikan produktivitas yang pada gilirannya meningkatkan bottom line dari industri manufaktur Nilai Severity, banyaknya Kejadian, Deteksi dan Risk Priority Number $(R P N)$ adalah beberapa parameter, yang perlu ditentukan. Ini adalah langkah-langkah yang diambil selama tahap desain dari siklus hidup peralatan untuk memastikan bahwa persyaratan keandalan telah dilakukan dengan benar dan bahwa proses untuk perbaikan terus-menerus ada.

\section{B. Permasalahan}

Berdasarkan latar belakang yang telah dipaparkan sebelumnya yang bersumber dari sebagai hasil-hasil kajian referensi dari jurnal-jurnal dan juga tinjuan pustaka yang mendukung penelitian ini, bawah state of art permasalahan yang mendasar dari $R P N$ Failure and Efect Analysis adalah bagaimana menerapkannya dalam cakupan cukup luas dalam berbagai bidang sebagai alat atau metode yang bermanfaat untuk membantu menjustifikasi pengambilan suatu keputusan dalam menentukan keandalan suatu sistem. Dari penelitian-penelitian yang sudah dilakukan penerapan Model ini banyak dilakukan di lingkungan industri, dan belum ada yang mengapilikasikannya dalam menganalisa mode kegagalan sistem pada peralatan Berat terutama yang dioperasikan disektor pertambangan.

Pada penelitian ini, berdarkan permasalahan yang mendasar tersebut diatas adalah untuk menguji apakah ada Perbedaan Dalam Risk Priority Number Failure Mode and Effects Analysis Pada Unit Sistem Alat Berat Heavy Duty Truck HD 785-7. Dimana sistem yang diuji adalah Power Train, Engine, Frame \& Body, Electrical, 
Hydraulic, Steering, Brake, Cooling, Lubrication, Operator Station, Autolube, Air Inlet \& exchaust, Fire Supression, Fuel dan Fatique alarm system. Selanjutnya sistem manakah yang mempunyai RPN tertinggi

\section{Tujuan}

Tujuan penelitian ini adalah untuk mengetahui apakah ada perbedaan dalam Risk Priority Number Failure Mode and Efect Analysis pada Unit Sistem Alat Berat Heavy Duty Truck HD 785-7 yang banyak diaplikasi sebagai sarana angkutan di industri pertambangan batubara. Kemudian menjusdifikasi berdasarkan analisis statistik sistem mana yang mempunyai resiko paling tinggi. Sehingga hasil dari pengujian ini bisa sabagai justifikasi untuk menentukan unit sistem mana yang mempunyai $R P N$ yang paling tinggi, sehingga bisa sebagai referensi untuk mengambil kebijakan dan pertimbangan dalam preventive maintanance dari unit.

Hipotesis dalam pengujian ini dirumuskan sebagai berikut :

Hipotesis untuk Homogenitas Varians

$\mathrm{H}_{0}: \sigma_{1}=\sigma_{2}=\sigma_{3}=\sigma_{4}=\sigma_{5}=\sigma_{6}=\sigma_{7}=\sigma_{8}=\sigma_{9}=\sigma_{10}=\sigma_{11}=\sigma_{12}=\sigma_{13}=\sigma_{14}=\sigma_{15}$

$\mathrm{H}_{1}$ : Satu atau lebih pasangan varians yaitu nilai $R P N$ sistem adalah berbeda

Hipotesis untuk perbedaan rata-rata

$\mathrm{H}_{0}: \mu_{1}=\mu_{2}=\mu_{3}=\mu_{4}=\mu_{5}=\mu_{6}=\mu_{7}=\mu_{8}=\mu_{9}=\mu_{10}=\mu_{11}=\mu_{12}=$

$\mu_{13}=\mu_{14}=\mu_{15}$

$\mathrm{H}_{1}$ : Satu atau lebih pasangan varians rata-rata yaitu nilai rata-rata $R P N$ sistem adalah berbeda

\section{LANDASAN TEORI}

A. Terminologi Failure Mode Effect and Analysis (FMEA)

Mochammad Basjir (2014) menjelaskan bahwa FMEA merupakan suatu tool penilaian yang penting untuk mengevaluasi potensi kegagalan yang kritis ketika sebuah kegagalan terjadi. Dalam rangka menganalisa dari failure mode yang terjadi, perlu dipahami beberapa terminologi yang berhubungan dengan penggunaan FMEA. Terminologi tersebut adalah

1. Komponen-komponen dari sistem atau alat yang yang dianalisa

2. Potential failure mode menggambarkan cara dimana sebuah produk atau proses bisa gagal untuk melaksanakan fungsi yang diperlukan sebagai gambaran keinginan, kebutuhan dan harapan dari internaldan eksternal customer. Penting untuk mempertimbangkan dan mencatat setiap potential failure mode yang terjadi dibawah kondisi operasi tertentu dan dibawah kondisi pemakaian tertentu (Pillay et all., 2003).

3. Failure Effect merupakan Dampak atau akibat yang ditimbulkan jika komponen tersebut gagal seperti disebutkan dalam potential failure mode. Dampak dari failure merupakan konsekuensi merugikan dari pengaruh failure tertentu yang mempengaruhi sistem atau subsistem lainnya. Beberapa failure dapat berdampak pada personal atau environment safety dan melanggar berbagai regulasi produk (Pillay et all., 2003).

4. Severity (S) merupakan kuantifikasi seberapa serius kondisi yang diakibatkan jika terjadi kegagalan yang akibatnya disebutkan dalam Failure Effect. Menurut tingkat keseriusan, severity dinilai pada skala 1 sampai 10 .

5. Causes Adalah apa yang menyebabkan terjadinya kegagalan pada komponen, subsistem atau sistem 
6. Occurance (O) Tingkat kemungkinan terjadinya kegagalan. Ditunjukkan dalam 10 level $(1,2, \ldots, 10)$ dari yang hampir tidak pernah terjadi (1) sampai yang paling mungkin terjadi atau sulit dihindari (10).

7. Detection (D) Menunjukkan tingkat kemung-kinan lolosnya penyebab kegagalan dari kontrol yang sudah dipasang. Levelnya juga dari 1-10, dimana angka 1 menunjukkan kemungkinan untuk lewat dari kontrol (pasti terdeteksi) sangat kecil, dan 10 menunjukkan kemungkinan untuk lolos dari kontrol (tidak terdeteksi) adalah sangat besar

8. Risk Priority Number $(R P N)$ Merupakan hasil perkalian bobot dari severity, occurance dan detection.

\section{B. Review Penelitian Terdahulu}

K. Palanikumar (2013) dalam Papernya Modified Prioritization Methodology for Risk Priority Number in Failure Mode and Effects Analysis menerngkan bahwa Prosedur FMEA memberikan nilai numerik untuk setiap risiko yang terkait dengan menyebabkan kegagalan menggunakan keparahan, kejadian dan deteksi indeks dan Risk Priority Number $(R P N)$ diperoleh dengan mengalikan nilai-nilai numerik. Metode prioritas tradisional FMEA memiliki dua kekurangan utama seperti: berbagai set keparahan, kejadian dan deteksi indeks dapat menghasilkan nilai identik RPN dan mengambil nilai numerik rata-rata atau lebih tinggi, ketika tim memiliki perselisihan dalam indeks peringkat. Dalam makalahnya ini melakukan usaha untuk mengembangkan metode $R P N$ prioritas baru untuk mengatasi dua kekurangan ini. Metode yang diusulkan telah dievaluasi oleh studi kasus dan teknik analisis statistik.

Sime Curkovicet et al (2013) dalam penelitiannya Using FMEA for Supply Chain Risk Management dimana tujuan dari penelitian ini adalah untuk mengetahui bagaimana perusahaan mengelola risiko supply chain, dengan fokus khusus pada penggunaan FMEA. Penelitian ini pertama menggunakan data survei untuk menentukan bahwa FMEA jarang digunakan untuk penilaian risiko pemasok, tetapi menyediakan alat yang ampuh untuk proaktif SCRM. Studi kasus ini kemudian diperiksa untuk menentukan bahwa banyak dari prinsip-prinsip dasar FMEA dapat diterapkan untuk mengurangi risiko dalam pemilihan supplier. Studi ini menunjukkan bahwa rantai pasokan benar-benar dapat dikelola dengan cara yang sama dengan produk dan proses cacat. Hasilnya menunjukkan bahwa dengan FMEA dapat memainkan peran utama dalam proses pengelolaan risiko melalui penilaian pemasok dan seleksi.

Pinnarat Nuchpho \& Santirat Nansaarng (2014) dalam Papernya Risk Assessment in the Organization by using FMEA Innovation. Dalam tulisannya meninjau makalah dalam periode 2002 hingga 2012 di jurnal internasional dan menemukan pendekatan menggunakan metode $R P N$ dalam organisasi paling populer. Jawaban ulasan ini akan memberikan indikasi tren saat ini dalam penelitian dan pedoman terbaik untuk penelitian masa depan dalam rangka untuk lebih mengatasi kekurangan dikenal terkait dengan FMEA tradisional.

M. Kostina et al (2012) dalam penelitiannya Reliability estimation for manufacturing processes dimana tujuan dari penelitianya adalah untuk mengembangkan metode penilaian reliabilitas dengan perpanjangan yang sudah ada dan pooling mereka untuk kerangka kerja umum. Sistem ini harus mengidentifikasi bagian yang paling diandalkan dari suatu proses produksi dan menyarankan cara yang paling efisien untuk peningkatan keandalan. Penelitian ini mengu-sulkan untuk memperpanjang FMEA dengan memperkenalkan klasifikasi kesalahan. Dalam prosedur ini, Bayesian Belief Network digunakan untuk menganalisis kesalahan. Temuan: Sebuah metode pemodelan terpadu berdasarkan pemodelan sistem dan dilengkapi dengan mekanisme evaluasi keandalan memiliki kemampuan untuk menganalisis dan merancang sistem manufaktur. Alat ini dikembangkan untuk menganalisis suatu proses produksi, memung-kinkan 
perusahaan untuk menganalisis proses secara keseluruhan serta bagian-bagiannya dan mencapai prognosis yang efisien untuk reorganisasi proses produksi.

M. Dudek-Burlikowska (2011) Dalam pene-litiannya Application of FMEA method in enterprise focused on quality, dimana tujuan dari penelitianya adalahs ebuah pendekatan baru untuk monitoring proses produksi dalam organisasi menggunakan Failure Mode dan metode Analisis. Kemungkinan penggunaan Failure Mode dan metode Analisis Efek adalah berhubungan dengan perbaikan mutu berkelanjutan organisasi Interdependensi, metode penelitian yang berkualitas dan memperhitungkan persyaratan proses produksi. Kesimpulannya adalah pada saat ini perusahaan harus mengintegrasikan manajemen kualitas dan kontrol kualitas dengan kebutuhan pelanggan, persyaratan proses produksi dan juga metode kualitas. Seperti jenis strategi akan memungkinkan untuk mencapai keberhasilan bagi perusahaan-perusahaan ini

Agung Sutrisno dan Tzong Ru Lee (2011) dalam penelitiannya Service reliability assessment using failure mode and effect analysis (FMEA): survey and opportunity roadmap, Melakukan survei literatur awal antara tahun 1994 dan 2010 yang mencakup 20 jurnal dari 8 database literatur yang berbeda. Hasil survei awal kami menunjukkan bahwa sebagian besar penelitian FMEA layanan sebelumnya berfokus pada keuntungan dan rantai pasokan berorientasi layanan praktek bisnis. Kesempatan penelitian layanan FMEA baru yang berkaitan dengan perangkat tambahan di Risk Priority Number (RPN), reprioritization, fleksibilitas penerapannya dalam kerangka rantai pasokan layanan dan sektor jasa non profit serta kombinasi dengan alat-alat kontrol kualitas lain diusulkan untuk penyelidikan lebih lanjut..

Swapnil B et al (2013) dalam penelitiannya A Review: Implementation of Failure Mode and Effect Analysis menyimpulkan bahwa Failure Mode and Effects Analysis (FMEA) adalah Prosedur dalam pengembangan produk dan manajemen operasi untuk analisis mode kegagalan potensial dalam sistem untuk klasifikasi dengan tingkat keparahan dan kemungkinan kegagalan. Kegiatan FMEA sukses membantu tim untuk mengidentifikasi potensi kegagalan mode berdasarkan pengalaman masa lalu dengan produk sejenis atau proses, memungkinkan tim untuk merancang egagalankegagalan dari sistem dengan minimum usaha dan pengeluaran sumber daya, sehingga mengurangi waktu pengembangan dan biaya.

Namdari $M$ et al (2011) Dalam penelitiannya Using the FMEA method to Optimize fuel consumption in Tillage by Moldboard Plow. Penerapan FMEA dalam penelitian ini mengungkapkan bahwa kecepatan membajak, kadar air tanah dan kedalaman membajak merupakan faktor yang paling penting dalam konsumsi bahan bakar pada pengolahan tanah, dengan 640, 480 dan 420 masing-masing $R P N$. Setelah menerapkan hasil yang disarankan oleh FMEA, konsumsi bahan bakar turun sebesar $16.40 \%$. Oleh karena itu bekerja dalam conditons dengan kelembaban tanah yang tepat, kedalaman membajak dan kecepatan membajak dapat menurunkan konsumsi bahan bakar dan isu-isu dampak lingkungan di persiapan lahan.

Swapnil B et al (2013) dalam penelitiannya A Review: Implementation of Failure Mode and Effect Analysis menyimpulkan bahwa Failure Mode and Effects Analysis (FMEA) adalah Prosedur dalam pengembangan produk dan manajemen operasi untuk analisis mode kegagalan potensial dalam sistem untuk klasifikasi dengan tingkat keparahan dan kemungkinan kegagalan. Kegiatan FMEA sukses membantu tim untuk mengidentifikasi potensi kegagalan mode berdasarkan pengalaman masa lalu dengan produk sejenis atau proses, memungkinkan tim untuk merancang egagalankegagalan dari sistem dengan minimum usaha dan pengeluaran sumber daya, sehingga mengurangi waktu pengembangan dan biaya.

Shivani Sharma \& Ravindra Pratap (2013) A Case Study of Risk Prioritazation Using FMEA Methode. Motif penting analisis ini untuk meninjau literatur dalam bidang berbagai faktor risiko rantai pasokan untuk memahami praktek saat ini dan untuk membantu Industri untuk mempertahankan nya terus menang di pasar datar di mana 
kompetisi menggorok leher di saat pasar Untuk mencapai tujuan ini langkah-langkah berikut telah dilakukan: Literatur tentang risiko pasokan serta Metode FMEA, SMEs (Subject Matter Experts in industry) inputs dan Sebuah Failure Mode dan Efek Analysis (FMEA) yang digunakan untuk mendapatkan risks Prioritizations

R. Suresh et al (2014) Dalam penelitiannya Risk Assessment for Blast Furnace Using FMEA. Dimana bertujuan untuk memperbaiki teknik penilaian risiko untuk menerapkan keamanan dalam implementasiknya pada pembuatan baja paduan Penilaian risiko menggunakan FMEA yang dilakukan pada pabrik baja tanur kapasitas 0.6MTPA (Metric Ton per tahun adalah) yang menghasilkan sekitar 1.000 ton logam panas yang disebut pig iron setiap hari. Risk Priority Number (RPN) membantu untuk mengetahui bahaya tertinggi dari kegiatan yang membutuhkan lebih banyak perhatian daripada kegiatan lainnya. Tindakan pengamanan yang disarankan dalam makalah ini dapat mencegah terjadinya kegagalan dan melindungi pekerja pada blast furnace dari kecelakaan fatal dan cedera

S.N.Waghmare et al (2014) Dalam Papernya Failure Mode Effect Analysis and Total Productive Maintenance: A Review diamana dalam paper ini mengulas berbagai pendekatan dari Pengaruh Failure Mode Effect Analysis dan Total Productive Maintenance telah dikembangkan selama ini dan diskusi tentang penggunaan FMEATPM dalam pendekatan terpadu

Mehrzad Ebrahemzadih et al (2014) Dalam Papernya Assessment and Risk Management of Potential Hazards by Failure Modes and Effect Analysis (FMEA) Method in Yazd Steel Complex. Dimana tujuan dari penelitian ini adalah untuk menilai potensi bahaya dengan metode FMEA pada Yazd Steel Complex. Metode: Dalam studi deskriptif mengevaluasi risiko di berbagai bagian kompleks dengan menggunakan metode FMEA dan dengan menggunakan FMEA Worksheet (PFMEA) yang berasal dari standar (MIL_STD-882). Temuan dalam penelitian ini menunjukkan bahwa gabungan steel maker lime dan pembuatan baja ingot mencapai $R P N$ tertinggi sebelum dan sesudah perbaikan langkah-langkah tindakan $(490,168)$ dan gabungan kesehatan lingkungan dan gaya gulungan mencapai RPN terendah sebelum dan sesudah tindakan tindakan korektif $(28,20)$. Kesimpulan: Hasil menunjukkan bahwa teknik FMEA dapat mengidentifikasi jumlah yang lebih tinggi dari bahaya daripada teknik lainnya. Titik pentingnya adalah bahwa pemilihan teknik yang tepat memainkan peran penting dalam mengidentifikasi tingkat yang lebih tinggi dari bahaya

Hadi Shirouyehzad, et al (2010) Dalam penelitiannya Fuzzy FMEA Analysis for Identification and Control of Failure Preferences in ERP Implementation. Dimana Fuzzy-FMEA digunakan sebagai teknik pencegahan untuk mengurangi tingkat kegagalan dalam implementasi ERP. Fuzzy-FMEA yang diusulkan juga mengidentifikasi penyebab kegagalan besar dan akibat cacat potensial dalam implementasi ERP dengan menggunakan bilangan fuzzy. Maka preferensi kegagalan dapat dicirikan oleh tingkat keparahan, kejadian dan deteksi nilai kabur dan Risk Priority Number

\section{METODOLOGI PENELITIAN}

\section{A. Pengambilan Data}

Data diambil dari data History Preventive Maintanance pada sebuah perusahaan tambang di Kalimantan Selatan, selama periode 5 tahun. Unit yang diuji nilai RPN dari sistem adalah Mine Truck Heavy Duty Truck HD 785-7. Sebagai sampel diambil 10 unit. Dari data preventif maintanance tersebut nilai RPN dihitung masing-masing sistem meliputi Power Train, Engine, Frame \& Body, Electrical, Hydraulic, Steering, Brake, Cooling, Lubrication, Operator Station, Autolube, Air Inlet \& exchaust, Fire Supression, Fuel dan Fatique alarm system. 


\section{B. Pengolahan Data}

Untuk melakukan pengujian terhadap perbedaan rata-rata, harus diuji apakah varian dari variabel adalah sama. Setelah diketahui bahwa data memenuhi asumsi homogentias varian, baru kemudian melakuan uji ANOVA dengan menggunakan uji F. Jika diperoleh hasil adanya perbedaan rata-rata, dilakukan analisis untuk setiap kelompok rata-rata atau pasangan rata-rata..

Pengujian data dengan menggunakan uji Posteriori (Post Hoc) untuk melihat sistem yang mana dari 15 sistem yang rata-ratanya nilai $R P N$ nya adalah paling kuat berbeda.

\section{HASIL DAN PEMBAHASAN}

\section{A. Data Nilai Risk Priority Number}

RPN atau Risk Priority Number Merupakan angka prioritas resiko yang didapatkan dari perkalian Severity, Occurrence, dan Detection. Hasil perhitungan RPN sebagaimana Tabel 1.

Tabel 1. Nilai Risk Priority Number Sistem

\begin{tabular}{|c|c|c|c|c|c|c|c|c|c|c|c|c|c|c|c|}
\hline \multirow[b]{2}{*}{ No. Unit } & \multicolumn{15}{|c|}{ SISTEM } \\
\hline & PT & EG & $\begin{array}{l}\text { F\& } \\
\text { B }\end{array}$ & EL & $\begin{array}{l}\text { HY } \\
\text { D }\end{array}$ & $\begin{array}{l}\text { ST } \\
\text { R }\end{array}$ & $\begin{array}{l}\mathrm{BR} \\
\mathrm{K} \\
\end{array}$ & $\begin{array}{l}\mathrm{CO} \\
\mathrm{L}\end{array}$ & $\begin{array}{l}\text { LU } \\
\text { B }\end{array}$ & $\begin{array}{l}\text { OP } \\
\mathrm{S}\end{array}$ & $\begin{array}{l}\mathrm{AU} \\
\mathrm{T}\end{array}$ & $\begin{array}{l}\mathrm{AI} \\
\mathrm{O}\end{array}$ & $\begin{array}{l}\mathrm{F} \\
\mathrm{R}\end{array}$ & FS & $\begin{array}{l}\text { FA } \\
\text { S }\end{array}$ \\
\hline $\begin{array}{l}\text { HD785- } \\
7-04\end{array}$ & $\begin{array}{r}19 \\
2\end{array}$ & $\begin{array}{r}14 \\
4\end{array}$ & 140 & 96 & 90 & 40 & 30 & 30 & 36 & 24 & 6 & 1 & 2 & 0 & 0 \\
\hline $\begin{array}{l}\text { HD785- } \\
7-05\end{array}$ & 72 & $\begin{array}{r}24 \\
0 \\
\end{array}$ & 225 & 180 & 80 & 0 & 60 & 4 & 0 & 30 & 16 & 4 & 0 & $\begin{array}{r}11 \\
2 \\
\end{array}$ & 0 \\
\hline $\begin{array}{l}\text { HD785- } \\
7-06\end{array}$ & 64 & $\begin{array}{r}27 \\
0\end{array}$ & 12 & 320 & 96 & 18 & 64 & 73 & 4 & 56 & 36 & 42 & 6 & 90 & 0 \\
\hline $\begin{array}{l}\text { HD785- } \\
7-07\end{array}$ & 32 & $\begin{array}{r}16 \\
8\end{array}$ & 24 & 320 & 90 & 6 & 80 & 30 & 32 & 70 & 108 & 128 & 0 & 56 & 0 \\
\hline $\begin{array}{l}\text { HD785- } \\
7-08\end{array}$ & 80 & 0 & 30 & 128 & 0 & 0 & 64 & 0 & 20 & 24 & 16 & 0 & 0 & 0 & 30 \\
\hline $\begin{array}{l}\text { HD785- } \\
7-09\end{array}$ & 0 & $\begin{array}{r}22 \\
4 \\
\end{array}$ & 8 & 192 & 0 & 12 & 140 & 16 & 0 & 2 & 0 & 0 & $\begin{array}{l}2 \\
4 \\
\end{array}$ & 28 & 30 \\
\hline $\begin{array}{l}\text { HD785- } \\
7-10\end{array}$ & $\begin{array}{r}19 \\
2\end{array}$ & 30 & 144 & 120 & 0 & 0 & 0 & 0 & 0 & 0 & 48 & 0 & $\begin{array}{l}1 \\
2 \\
5\end{array}$ & 30 & 10 \\
\hline $\begin{array}{l}\text { HD785- } \\
7-11\end{array}$ & 0 & 0 & 80 & 160 & 0 & 36 & 0 & 0 & 0 & 16 & 36 & 24 & $\begin{array}{l}2 \\
0\end{array}$ & 48 & 63 \\
\hline $\begin{array}{l}\text { HD785- } \\
7-12\end{array}$ & 84 & $\begin{array}{r}24 \\
0 \\
\end{array}$ & 126 & 216 & 108 & 180 & 0 & 0 & 0 & 100 & 150 & 0 & 0 & 0 & 36 \\
\hline $\begin{array}{l}\text { HD785- } \\
7-14\end{array}$ & $\begin{array}{r}12 \\
0\end{array}$ & 0 & 96 & 245 & 0 & 96 & 120 & 0 & 0 & 200 & 0 & 0 & 0 & 54 & 70 \\
\hline
\end{tabular}

PT: Power Train, EG: Engine, F\&B: Frame \& Body, HYD: Hydraulic, STR: Steering, BRK: Brake, COL: Cooling, LUB: Lubrication, OPS: Operator Station, AUT: Auto Lube: AIO: Air Inlet Outlet, FS: Fuel System, FAS: Fatigue Alarm System

\section{B. Pengolahan dan Analisa Data}

Pengujian data dengan Posteriori (Post Hoc). Pengujian yang digumakan adalah uji Tukey HSD dan Duncan. Hal in karena Hipotesis diambil setelah data dikumpulkan dan diperiksa awal. Jadi untuk melakukan pengujian seperti ini yang digambarkan adalah pengujian Posteriori atau Post Hoc.

Uji Tukey atau disebut juga Tukey Honestly Significant Difference (HSD) merupakan pengjujian perbadningan berbagai kelompok rata-rata. Uji Tukey menggunakan statistik range studentized untuk membuat semua perbandingan berpasangan antar group dan menentukan kesalahan kelompok percobaan untuk membuat perbandingan berpasangan. 
Uji range Duncan juga digunakan untuk menguji perbandingan berpasangan antar beberapa rata-rata. Sehingga dengan uji ini bisa ddiketahui kelompok rata-rata mana yang berbeda dan kelompok yang berisi variabel yang sama. Hasil pengjujian dengan bantuan SPSS 19 didapat hasil sebagai berikut:

Nilai RPN

Tabel 2. Descriptives

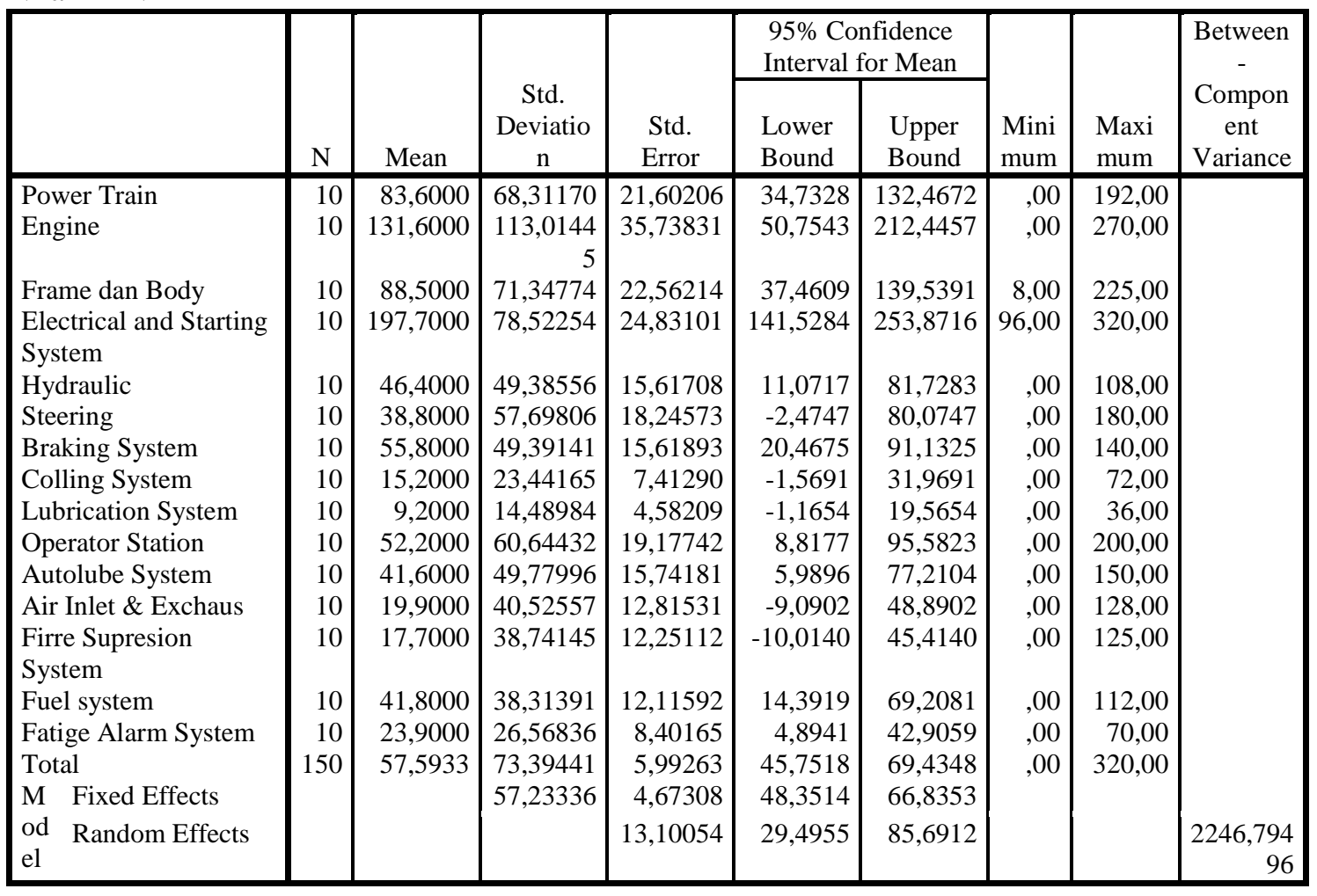

Tabel 3. Test of Homogeneity of Variances

Nilai RPN

\begin{tabular}{|r|r|r|r|}
\hline $\begin{array}{c}\text { Levene } \\
\text { Statistic }\end{array}$ & df1 & df2 & Sig. \\
\hline 4,914 & 14 & 135 &, 000 \\
\hline
\end{tabular}

Tabel 4. ANOVA

Nilai RPN

\begin{tabular}{|l|c|r|c|c|c|}
\hline & \multicolumn{1}{|c|}{$\begin{array}{c}\text { Sum of } \\
\text { Squares }\end{array}$} & \multicolumn{1}{c|}{ df } & \multicolumn{1}{c|}{$\begin{array}{c}\text { Sean } \\
\text { Square }\end{array}$} & F & Sig. \\
\hline $\begin{array}{l}\text { Between } \\
\text { Groups }\end{array}$ & 360410,493 & 14 & 25743,607 & 7,859 &, 000 \\
$\begin{array}{l}\text { Within } \\
\text { Groups } \\
\text { Total }\end{array}$ & 442213,700 & 135 & 3275,657 & & \\
\hline
\end{tabular}

Dari hasil pengolahan data tersebut terlihat bahwa Levene Statistik adalah 4,914 dengan nilai sig sebesar 0,000, yang berarti varian dari nilai RPN untuk setiap sistem adalah sama. Sedangkan dengan melihat nilai $\mathrm{F}$ hitung sebesar 7,859 dengan nilai sig sebesar 0,000. Dengan hasil tesebut dimana F tabel sebesar 1,77 yaitu F hitung lebih besar dari F tabel bararti rata-rata nilai RPN setiap sistem adalah berbeda. 
Perbedaan rata-rata dari milai RPN adalah signifikan, selanjutnya sistem yang berbeda niali RPN nya dapat dianalisa dari hasil output analisis dengan perbandingan simultan (multiple comparation). Tanda bintang pada Mean Defference atau nilai Sig yang lebih kecil dari alpha (5\%), terlihat bahwa terdapat pasangan rata-rata.Power Trani dengan Electrical Sytem yaitu sig 0,02, Engine dengan Steering sig 0,03, Engine dengan Cooling system 0,01, Engine dengan Lubrication 0,000, Engine dengan Autolube system 0,042, Engine dengan Air Inlet Exchaust 0,02, Engine dengan Fire Suppretion system 0,02, Engine dengan Fuel system 0,043, Engine dengan Fatigue Alarm system 0,004, Frame \& Body dengan Electric 0,03, Electric dengan Hydraulic 0,000, Electric dengan Steering 0,000, Electric dengan Brake 0,000, Electric dengan Colling system 0,000, Electric dengan Air Inlet Exchaust 0,000, Elecric dengan Fire Suppretion system 0,000, Electric dengan Fuel System 0,000, Electric dengan Fatigue Alarm system 0,000. Subset.

Untuk melihat kelompok rata-rata perbedaan dilihat pada output Homogeneus

Tabel 5. Homogeneus Subset

Nilai RPN

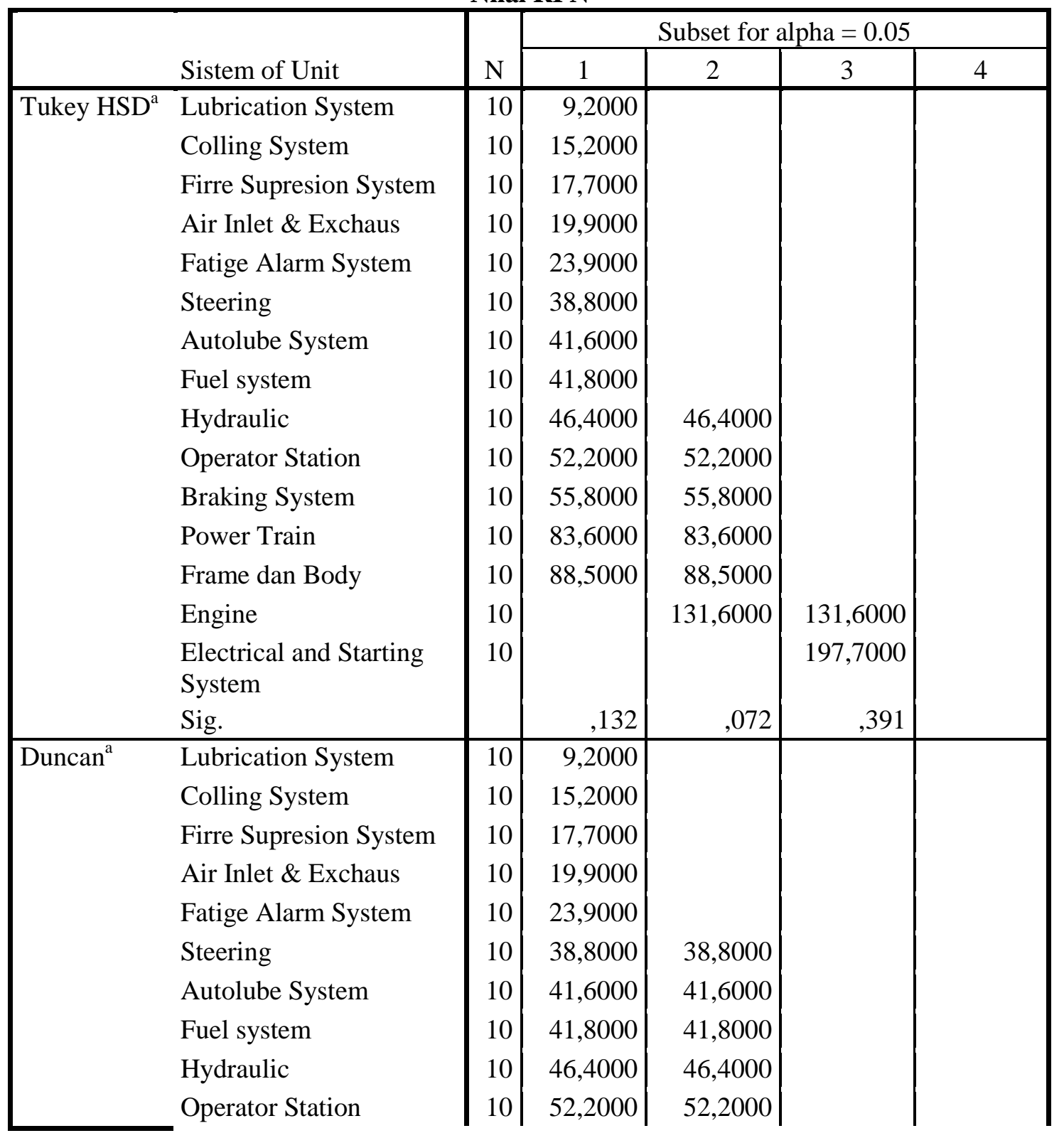




\begin{tabular}{|l|r|r|r|r|r|}
\hline Braking System & 10 & 55,8000 & 55,8000 & & \\
Power Train & 10 & & 83,6000 & 83,6000 & \\
Frame dan Body & 10 & & 88,5000 & 88,5000 & \\
Engine & 10 & & & 131,6000 & \\
Electrical and Starting & 10 & & & & 197,7000 \\
System & & & & & \\
Sig. & &, 135 &, 101 &, 078 & 1,000 \\
\hline
\end{tabular}

Means for groups in homogeneous subsets are displayed.

a. Uses Harmonic Mean Sample Size $=10,000$.

Dari output terlihat bahwa rata-rata nilai RPN pada Tukey HSD untuk jenis sistem terbagi menjadi tiga kelompok berbeda. Kelompok pertama adalah terdiri dari sistem Power Train, Frame \& Body, Hydraulic, Steering, Brake, Cooling, Lubrication, Operator Station, Autolube, Air Inlet \& exchaust, Fire Supression, Fuel dan Fatique alarm system. Kelompok kedua terdiri dari sistem, Power Train, Engine, Frame \& Body, Hydraulic, dan Operator Station, Kelompok ketiga adalah Engine, Electrical System.. Dengan melihat pembagian kelompok tersebut terlihat bahwa rata-rata nilai $R P N$ sistem yang berbeda adalah Lubrication system, Engine dan Electric. Nilai RPN yang paling rendah adalah Lubrication system dengan rata-rata 9,2 dan yang tertinggi adalah pada Electric System dengan rata-rata RPN 197,7.

Berdasarkan analisis statistik diatas terlihat bahwa dengan uji Tukey HSD maupun uji Duncan terlihat bahwa sama-sama ada perbedaan kelompok rata-rata nilai $R P N$ terbesar adalah Electrical system.

\section{KESIMPULAN DAN SARAN}

\section{A. Kesimpulan}

Dari hasil pembahasan bisa disimpulkan bahwa ada perbedaan rata-rata nilai $R P N$ dari masing-masing sistem. Pada hasil pengujia Tukey HSD maupun Duncan rata-rata nilai $R P N$ dibagi dalam tiga kelompok beda. Rata-rata nilai $R P N$ yang terendah adalah Lubrication sistem dengan rata-rata nilai $R P N 92$ dan yang tertinggi adalah Electrical System dengan rata-rata $R P N$ 197,7

\section{B. Saran}

Disarankan buat penelitian berikutnya adalah menguji pengaruh dari nilai $R P N$ rata-rata masing-masing sistem unit terhadap Mechanical Availability.

\section{DAFTAR PUSTAKA}

[1] Agung Sutrisno dan Tzong Ru Lee (2011), Service reliability assessment using failure mode and effect analysis (FMEA): Survey and Opportunity Roadmap, International Journal of Engineering, Science and Technology, Vol. 3, No. 7, pp. 2538

[2] Bolwes, J.B. (1998). The new SAE FMECA standard, Proceeding Annual Reliability and Maintainability Symposium, pp.48-53.

[3] Bendaya, M. and Raouf, A. (1996). A Revised Failure mode and effects analysis model. International journal of quality reliability management, Vol.13, pp.43-47.

[4] Ebrahimipour, V., Rezai e, K., Shokravi , S. (2010). An Ontology Approach to Support FMEA Studies, Expert Systems with Applications”, 37, pp 671-677

[5] Gilchrist, W. (1993). Modelling failure modes and effects analysis, International Journal of Quality \& Reliability Management, Vol.10, No.5, pp.16-23.

[6] Hung, G.Q., Nie, M. and Mark, K.L. (1999). Web-based failure mode and effect analysis, Computers \& Industrial Engineering, Vol.37, pp.177-180. 
[7] Hadi Shirouyehzad, Mostafa Badakhshian, Reza Dabestani, , Hamidreza Panjehfouladgaran, (2010), Fuzzy FMEA Analysis for Identification and Control of Failure Preferences in ERP Implementation, The Journal of Mathematics and Computer Science Vol .1 No.4, pp. 366-376

[8] Kara-Zaitri, C. and Fleming, P.V. (1997). Applications of fuzzy Inference Methods to Failure Modes Effects and Criticality Analysis IFMECA, International Conference on Safety and Reliability, pp.2403-2414

[9] Mehrzad Ebrahemzadih, G. H. Halvani,, Behzad Shahmoradi, Omid Giahi, (2014) , Assessment and Risk Management of Potential Hazards by Failure Modes and Effect Analysis (FMEA) Method in Yazd Steel Complex. Open Journal of Safety Science and Technology, pp. 127-135

[10] M. Dudek-Burlikowska (2011), Application of FMEA Method in Enterprise Focused on Quality, Journal of Achievements in Materials and Manufacturing Engineering, Volume 45, pp 89-102

[11] Mochammad Basjir , Hari Supriyanto , Mokh. Suef, Pengambangan Model Penentuan Prioritas Perbaikan Terhadap Mode Kegagalan Komponen Dengan Metodologi FMEA Fuzyy dan Topsis yang TerintegrasiI http://digilib.its.ac.id/public/ITS-Master-15513Paper-pdf.pdf September 2014

[12] M. Kostina a, T. Karaulova J. Sahno M. Maleki, (2012) Reliability Estimation for Manufacturing Processes, Journal of Achievements in Materials and Manufacturing Engineering, Volumw 51, pp 7-13

[13] Namdari M., Rafiee Sh., Jafari A (2011) Using the FMEA method to Optimize fuel consumption in Tillage by Moldboard Plow, International Journal of Applied Engineering Research Dindigul, Volume 1, No 4, pp 732-742

[14] Ningcong Xiao, Hong-Zhong Huang, Yanfeng Li, , Liping He, Tongdan Jin, (2011), Multiple failure modes analysis and weighted risk priority number evaluation in FMEA, Engineering Failure Analysis 18, pp 1162-1170

[15] N. Sellappan dan K. Palanikumar (2013) , Modified Prioritization Methodology for Risk Priority Number in Failure Mode and Effects Analysis, International Journal of Applied Science and Technology, Vol. 3 No. 4, pp 27-36

[16] Pillay, A., Wang, J. (2003), Modified Failure Mode and Effects Analysis Using Approximate Reasoning, Reliability Engineering \& System Safety 139, pp 379394.

[17] Pinnarat Nuchpho \& Santirat Nansaarng (2014), Risk Assessment in the Organization by using FMEA Innovation, Proceedings of the 7th International Conference on Educational Reform, Innovations and Good Practices in Education: Global Perspectives, pp 781-789

[18] R. Suresh, , M. Sathyanathan, K. Visagavel, M. Rajesh Kuma, (2014), Risk Assessment for Blast Furnace Using FMEA, International Journal of Research in Engineering and Technology, Volume: 03 Special Issue: 11, pp. 27-31

[19] Sime Curkovic, Thomas Scannell and Bret Wagner, (2013), Using FMEA for Supply Chain Risk Management, Modern Management Science \& Engineering, Vol. 1, No. 2, pp 251-265

[20] Swapnil B. Ambekar, Ajinkya Edlabadkar, Vivek Shrouty, (2013), A Review: Implementation of Failure Mode and Effect Analysis, International Journal of Engineering and Innovative Technology (IJEIT), Volume 2, Issue 8, pp. 37-41

[21] Shivani Sharma \& Ravindra Pratap (2013) A Case Study of Risk Prioratization Using FMEA Method, International Journal of Scientific and Research Publications, Volume 3 , Issue 10, pp 1-4

[22] S.N.Waghmare, Dr.D.N.Raut, Dr.S.K.Mahajan, Dr.S.S.Bhamare, (2014), Failure Mode Effect Analysis and Total Productive Maintenance: A Review, International Journal of Innovative Research in Advanced Engineering (IJIRAE), Volume 1 Issue 6, pp 183-203 
[23] Sime Curkovic Thomas Scannell and Bret Wagner, (2013), Using FMEA for Supply Chain Risk Management, Modern Management Science \& Engineering Vol. 1, No. 2 pp 251-265. 